\title{
The Influence of Fertilization and Perennial Grasses and Legumes Mixture on the Structure of Vegetation Cover in Temporary Meadows under the Center of Moldova Conditions
}

\author{
Margareta NAIE ${ }^{1 *}$, Vasile VINTU ${ }^{1}$, Elena TROTUS ${ }^{2}$, Simona POCHISCANU ${ }^{1}$ \\ ${ }^{1}$ University of Agricultural Sciences and Veterinary Medicine, Iasi, Romania. \\ ${ }^{2}$ Agricultural Research - Development Station, Secuieni, Romania \\ *Corresponding author: naie.marieta@yahoo.com
}

Bulletin USAMV series Agriculture 72(2)/2015

Print ISSN 1843-5246; Electronic ISSN 1843-5386

DOI 10.15835/buasvmcn-agr: 11445

\begin{abstract}
In S.C.D.A. Secuieni conditions, during 2013-2014, were carried out researches on the structure of vegetation cover, at five mixtures of perennial grasses and legumes, under the influence of some nitrogen fertilizers on a phosphorus agrofond. The obtained results revealed that the share of grasses in mixtures decreases from I scythe to the III scythe, instead the proportion of legumes increased. By increasing the dose of nitrogen fertilizer the competitiveness capacity of grasses increase at the expense of legumes and different species.
\end{abstract}

Keywords: fertilization, mixtures, perennial grasses, perennial legumes, temporary meadows.

\section{INTRODUCTION}

The perennial legumes and grasses react differently to the application of fertilizers with macroelements. In order to provide a balanced nutrition to the plants, due to the synergistic interactions, the nitrogen fertilizers are given on a phosphorus and potassium agrofond. The phosphorus fertilizers stimulate the growth of legumes, and the nitrogen ones stimulates the grasses growth. The legumes get their necessary nitrogen for their own need through symbiotic mocroorganisms and put a part of it available to the grasses from the mixture, causing the reduction of nitrogen fertilizers (Carlsson et al., 2006).

In the temporary meadows changes occur in the floristic composition of the herbaceous cover due to the pedoclimatic conditions from the cultivation area, of the agro - technical measures applied, of the exploitation system, and the aggressiveness of the mixed species (Moga and Schitea, 2005; Moga et al., 2007). For this purpose, at the Agricultural Research - Development Station Secuieni, during 2013 - 2014, were conducted researches regarding the dynamics of some perennial grasses and legumes species in complex mixtures, and the changes recorded in the structure of the vegetation cover during the exploitation period.

The composition of the mixtures is the most important work in temporary grassland cultivation technology, on which largely depends the production and evolution of the vegetation cover composition (Rotar et al., 1997).

The choice of species in order to constitution the mixtures of perennial grasses and legumes is based on the stationary conditions, the manner 
and duration of use, and the competitive ability of the species (Vintu et al., 2010).

\section{MATERIALS AND METHODS}

The researches were conducted at the Agricultural Research - Development Station Secuieni, from Neamt county, on a chernozem soil type (SRTS, 2012) with slightly acidic pH (6.29), the humus content of $2.55-3.10 \%$, middle stocked in $\mathrm{N}$ and well stocked in $\mathrm{P}_{2} \mathrm{O}_{5}$ and $\mathrm{K}_{2} \mathrm{O}$, capitalizing a polifactorial experience with complex mixtures of perennial grasses and legumes.

The experience was founded in the spring of 2013, after the subdivided parcels method with two factors, being the Ax B type, in four repetitions. The studied factors were: A - fertilization, with four graduations: $\mathrm{a}_{1}-\mathrm{N}_{0} \mathrm{P}_{0} ; \mathrm{a}_{2}-\mathrm{N}_{40} \mathrm{P}_{40} ; \mathrm{a}_{3}-\mathrm{N}_{80} \mathrm{P}_{40}$; $\mathrm{a}_{4}-\mathrm{N}_{80+40} \mathrm{P}_{40} ; \mathrm{B}$ - mixture of perennial grasses and legumes, with five graduations: $b_{1}-20 \%$ grasses $+80 \%$ legumes $(20 \%$ Dactylis glomerata L. $+80 \%$ Medicago sativa L.); $\mathrm{b}_{2}-65 \%$ grasses + $35 \%$ legumes $(30 \%$ Bromus inermis Leyss $+35 \%$ Dactylis glomerata L. $+35 \%$ Onobrychis viciifolia Scop.); $b_{3}-70 \%$ grasses $+30 \%$ legumes $(30 \%$ Dactylis glomerata L. $+40 \%$ Lolium perenne L. + $20 \%$ Medicago sativa L. $+10 \%$ Lotus corniculatus L.); $b_{4}-70 \%$ grasses $+30 \%$ legumes (30\% Festuca arundinacea Schreb. + 20\% Dactylis glomerata L.
+ 20\% Festuca pratensis Huds. + 20\% Medicago sativa $\mathrm{L} .+10 \%$ Trifolium pratense $\mathrm{L}.) ; \mathrm{b}_{5}-80 \%$ grasses $+20 \%$ legumes (45\% Festuca pratensis Huds. + 35\% Festuca arundinacea Schreb. + 20\% Trifolium pratense L.).

The phosphate fertilizers were administered in fall, and those based on nitrogen were administered in early spring, except $\mathrm{N}_{80+40}$ graduation, whose difference was administered after the first scythe.

In order to achieve the mixtures was used a diverse genetic material, represented by five species of perennial grasses and three of legumes. At the perennial grasses were used the varieties: 'Intensiv' (orchard grass), 'Doina' (non aristed brome), 'Mara' (perennial ryegrass), 'Barelite' (tall fescue), 'Barvital' (meadow fescue), and at legumes, 'Mihaela' (alfalfa), 'Splendid' (sainfoin) and 'Rotrif' (red clover).

The surface of one experimental plot was of 10 $\mathrm{m}^{2}$, and the harvested area was of $8 \mathrm{~m}^{2}$. From each plot were collected samples after the gravimetric method and was followed the floristic evolution on group of species (grasses, legumes and species from other botanical families).

The results presented in this paper are obtained in 2014, the harvest being done in

Tab. 1. Climatic data recorded at ARDS Secuieni in 2013-2014 agricultural year

\begin{tabular}{|c|c|c|c|c|c|c|c|c|c|c|c|c|c|c|}
\hline \multirow{2}{*}{\multicolumn{2}{|c|}{ Specification }} & \multicolumn{3}{|c|}{2013} & \multicolumn{10}{|c|}{2014} \\
\hline & & X & XI & XII & I & II & III & IV & V & VI & VII & VIII & IX & Media \\
\hline \multirow{6}{*}{ 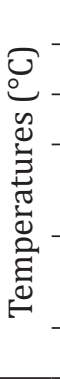 } & I decade & 6.6 & 10.8 & -0.7 & 0.7 & -5.7 & 4.0 & 8.0 & 12.9 & 19.1 & 20.3 & 22.6 & 18.4 & \\
\hline & II decade & 11.3 & 6.2 & -0.9 & 1.2 & -0.4 & 8.1 & 8.2 & 14.6 & 17.8 & 20.1 & 21.7 & 16.2 & \\
\hline & III decade & 11.9 & 4.5 & 0.1 & -8.9 & 1.2 & 9.0 & 13.7 & 18.6 & 17.6 & 21.8 & 17.8 & 12.8 & \\
\hline & $\begin{array}{l}\text { Monthly } \\
\text { average }\end{array}$ & 9.9 & 7.1 & -0.5 & -2.3 & -1.6 & 7.0 & 10.0 & 15.3 & 18.1 & 20.7 & 20.7 & 15.8 & 9.2 \\
\hline & $\begin{array}{c}\text { Multiannual } \\
\text { average }\end{array}$ & 9.1 & 3.4 & -1.8 & -3.9 & -2.2 & 2.5 & 9.3 & 15.3 & 18.7 & 20.2 & 19.3 & 14.7 & 8.7 \\
\hline & Deviation & 0.8 & 3.7 & 1.3 & 1.6 & 0.6 & 4.5 & 0.7 & 0.2 & -0.6 & 0.5 & 1.4 & 1.1 & 0.5 \\
\hline \multirow{6}{*}{ 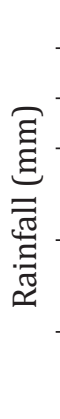 } & I decade & 11.6 & 2.6 & 0.2 & 0.6 & 0.2 & 13.8 & 11.0 & 9.8 & 39.4 & 29.0 & 0.0 & 0.0 & \\
\hline & II decade & 2.8 & 1.4 & 10.2 & 8.4 & 4.2 & 8.0 & 58.6 & 47.4 & 10.8 & 31.2 & 15.4 & 0.0 & \\
\hline & III decade & 0.4 & 34.8 & 1.0 & 13.6 & 2.4 & 4.6 & 8.2 & 39.0 & 16.4 & 30.9 & 21.6 & 9.2 & \\
\hline & $\begin{array}{l}\text { Monthly } \\
\text { amount }\end{array}$ & 14.8 & 38.8 & 11.4 & 22.6 & 6.8 & 26.4 & 77.8 & 96.2 & 66.6 & 91.1 & 37.0 & 9.2 & 498.7 \\
\hline & $\begin{array}{c}\text { Multiannual } \\
\text { average }\end{array}$ & 35.2 & 28.1 & 26.3 & 21.0 & 19.4 & 24.8 & 46.3 & 64.8 & 85.0 & 86.0 & 64.0 & 47.1 & 548.0 \\
\hline & Deviation & -20.4 & 10.7 & -14.9 & 1.6 & -12.6 & 1.6 & 31.5 & 31.4 & -18.4 & 5.1 & -27.0 & -37.9 & 49.3 \\
\hline
\end{tabular}


hayfield regime, at the earing of the dominant grasses and buding of legumes.

Regarding the climatic conditions, in 2013/2014 agricultural year the recorded temperatures were with $0.5^{\circ} \mathrm{C}$ higher than the annual average, and the rainfall recorded a deficit of $49.3 \mathrm{~mm}$ from the annual average (Tab. 1).

\section{RESULTS AND DISCUSSION}

The mixtures of species included in the study presented high adaptability to the climatic conditions in which were tested. Due th the researches carried out at A.R.D.S Secuieni it was noted that the mixtures of perennial grasses and legumes studied, moderate fertilized with chemical fertilizers, lends itself to intensive culture and can be used in hayfield regime.

From the analysis of the floristic composition dynamics in 2014, it was observed that this depends on the interaction between species from the mixtures, climatic conditions during the forming of the harvest and on the doses of chemical fertilizers applied. In the analyzed period, under the climatic conditions of A.R.D.S. Secuieni, at the experimented mixtures was obtained a number of 3 scythes, and the exploitation period was of 143 days.

At the mixture formed from $20 \%$ grasses and $80 \%$ legumes (20\% Dactylis glomerata $+80 \%$ Medicago sativa), it was found that in 2014, was recorded a floristic composition consisting from

Tab. 2. The influence of the mixture and fertilization on the floristic composition in 2014

\begin{tabular}{|c|c|c|c|c|c|c|c|c|c|c|c|c|}
\hline \multirow{3}{*}{ Variant } & \multicolumn{3}{|c|}{ Grasses\% } & \multirow[b]{2}{*}{ M } & \multicolumn{3}{|c|}{ Legumes\% } & \multirow{2}{*}{ M } & \multicolumn{3}{|c|}{ Various \% } & \multirow[b]{2}{*}{ M } \\
\hline & I scythe & II scythe & $\begin{array}{c}\text { III } \\
\text { scythe }\end{array}$ & & I scythe & I scythe & $\begin{array}{c}\text { III } \\
\text { scythe }\end{array}$ & & I scythe & II scythe & $\begin{array}{c}\text { III } \\
\text { scythe }\end{array}$ & \\
\hline & \multicolumn{12}{|c|}{$20 \%$ grasses $+80 \%$ legumes $(20 \% \mathrm{Dg}+80 \% \mathrm{Ms})$} \\
\hline $\mathrm{N}_{0} \mathrm{P}_{0}$ & 37 & 42 & 23 & 34 & 62 & 55 & 71 & 63 & 1 & 3 & 6 & 3 \\
\hline $\mathrm{N}_{40} \mathrm{P}_{40}$ & 36 & 44 & 36 & 39 & 62 & 51 & 56 & 56 & 1 & 5 & 8 & 5 \\
\hline $\mathrm{N}_{80} \mathrm{P}_{40}$ & 46 & 26 & 23 & 32 & 52 & 69 & 65 & 62 & 2 & 5 & 12 & 6 \\
\hline \multirow[t]{2}{*}{$\mathrm{N}_{80+40} \mathrm{P}_{40}$} & 46 & 51 & 30 & 42 & 54 & 44 & 62 & 53 & 1 & 4 & 9 & 5 \\
\hline & \multicolumn{12}{|c|}{$65 \%$ grasses $+35 \%$ legumes $(30 \% \mathrm{Bi}+35 \% \mathrm{Dg}+35 \% \mathrm{Ov})$} \\
\hline $\mathrm{N}_{0} \mathrm{P}_{0}$ & 65 & 51 & 26 & 47 & 35 & 46 & 68 & 50 & 1 & 4 & 6 & 4 \\
\hline $\mathrm{N}_{40} \mathrm{P}_{40}$ & 71 & 32 & 35 & 46 & 27 & 63 & 60 & 50 & 2 & 5 & 6 & 4 \\
\hline $\mathrm{N}_{80} \mathrm{P}_{40}$ & 75 & 60 & 28 & 54 & 24 & 36 & 62 & 41 & 0 & 4 & 10 & 5 \\
\hline $\mathrm{N}_{80+40} \mathrm{P}_{40}$ & 70 & 54 & 57 & 60 & 30 & 47 & 43 & 40 & 0 & 0 & 0 & 0 \\
\hline \multicolumn{13}{|c|}{$70 \%$ grasses $+30 \%$ legumes $(30 \% \mathrm{Dg}+40 \% \mathrm{Lp}+20 \% \mathrm{Ms}+10 \% \mathrm{Lc})$} \\
\hline $\mathrm{N}_{0} \mathrm{P}_{0}$ & 61 & 43 & 30 & 45 & 37 & 51 & 55 & 48 & 2 & 6 & 15 & 8 \\
\hline $\mathrm{N}_{40} \mathrm{P}_{40}$ & 65 & 33 & 22 & 40 & 34 & 57 & 62 & 51 & 1 & 10 & 16 & 9 \\
\hline $\mathrm{N}_{80} \mathrm{P}_{40}$ & 60 & 55 & 19 & 45 & 39 & 35 & 67 & 47 & 1 & 10 & 15 & 9 \\
\hline $\mathrm{N}_{80+40} \mathrm{P}_{40}$ & 72 & 41 & 27 & 47 & 27 & 54 & 62 & 48 & 1 & 5 & 11 & 6 \\
\hline \multicolumn{13}{|c|}{$70 \%$ grasses $+30 \%$ legumes $(30 \% \mathrm{Fa}+20 \% \mathrm{Dg}+20 \% \mathrm{~F} \mathrm{p}+20 \% \mathrm{Ms}+10 \% \mathrm{Tp})$} \\
\hline $\mathrm{N}_{0} \mathrm{P}_{0}$ & 70 & 25 & 26 & 40 & 28 & 73 & 65 & 55 & 2 & 3 & 9 & 5 \\
\hline $\mathrm{N}_{40} \mathrm{P}_{40}$ & 60 & 31 & 28 & 40 & 39 & 64 & 62 & 55 & 1 & 5 & 10 & 5 \\
\hline $\mathrm{N}_{80} \mathrm{P}_{40}$ & 63 & 24 & 29 & 39 & 37 & 73 & 58 & 56 & 1 & 3 & 13 & 6 \\
\hline $\mathrm{N}_{80+40} \mathrm{P}_{40}$ & 59 & 40 & 39 & 46 & 39 & 60 & 61 & 53 & 1 & 0 & 0 & 0 \\
\hline \multicolumn{13}{|c|}{$80 \%$ grasses $+20 \%$ legumes $(45 \% \mathrm{Fp}+35 \% \mathrm{Fa}+20 \% \mathrm{Tp})$} \\
\hline $\mathrm{N}_{0} \mathrm{P}_{0}$ & 75 & 17 & 17 & 36 & 22 & 82 & 79 & 61 & 3 & 2 & 4 & 3 \\
\hline $\mathrm{N}_{40} \mathrm{P}_{40}$ & 67 & 26 & 29 & 41 & 32 & 72 & 61 & 55 & 1 & 2 & 10 & 4 \\
\hline $\mathrm{N}_{80} \mathrm{P}_{40}$ & 61 & 20 & 33 & 38 & 38 & 76 & 54 & 56 & 1 & 4 & 13 & 6 \\
\hline $\mathrm{N}_{80+40} \mathrm{P}_{40}$ & 75 & 53 & 50 & 59 & 24 & 42 & 35 & 34 & 1 & 6 & 16 & 8 \\
\hline
\end{tabular}



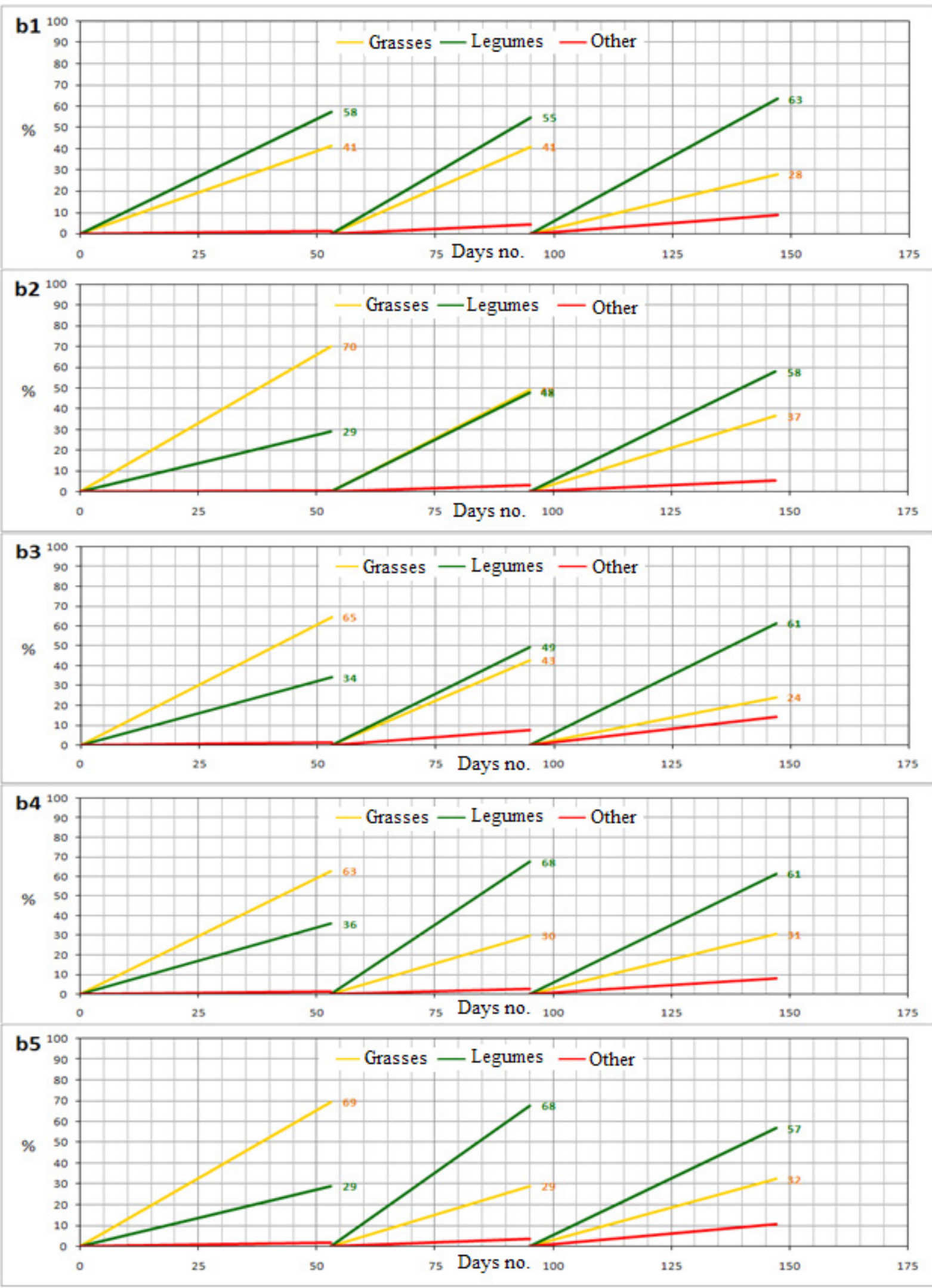

Fig. 1. The dynamics of biomass accumulation and the share of the groups of species at its composition 
23-46\% grasses $\left(\mathrm{N}_{0} \mathrm{P}_{0}\right.$ - III scythe, respectively $\mathrm{N}_{80} \mathrm{P}_{40}$ - I scythe), 44-71\% legumes $\left(\mathrm{N}_{80+40} \mathrm{P}_{40}-\right.$ II scythe, respectively $\mathrm{N}_{0} \mathrm{P}_{0}$ - III scythe) and 1-12\% species from other botanical families (Tab. 2).

Analyzing the data obtained at this mixture in average on all harvest cycles, it was found that the percentage of grasses ranged between $32-42 \%$, the legumes, between $53-63 \%$, and the percentage of plants from other species has been between $3-6 \%$ of the herbaceous cover. It was found that by increasing the dose of nitrogen up to $120 \mathrm{~kg} /$ ha a.s., the grasses percentage increase (42\% - $\mathrm{N}_{80+40} \mathrm{P}_{40}$ ) and the legumes decreasese (53\% $\mathrm{N}_{80+40} \mathrm{P}_{40}$ ).

At the mixture with $65 \%$ grasses $+35 \%$ legumes $(30 \%$ Bromus inermis $+35 \%$ Dactylis glomerata $+35 \%$ Onobrychis viciifolia), it was observed that the grasses participated in the formation of herbaceous cover in an amount of $26 \%\left(\mathrm{~N}_{0} \mathrm{P}_{0}\right.$ - III scythe) and $75 \%\left(\mathrm{~N}_{80} \mathrm{P}_{40}\right.$ - I scythe $)$, and the legumes percentage in an amount of $24 \%$ $\left(\mathrm{N}_{80} \mathrm{P}_{40}\right.$ - I scythe) and $68 \%\left(\mathrm{~N}_{0} \mathrm{P}_{0}-\right.$ III scythe).

Due to the results obtained, it was found that the variant fertilized with $\mathrm{N}_{80+40} \mathrm{P}_{40}$ averaged over the three scythes, there were recorded values very close to the percentage established by seeding, respectively, the one of $60 \%$ grasses and $40 \%$ legumes. The species from the various plant group were presented in an average percentage ranging between $0-5 \%$.

The evolution of the floristic composition at the mixture consisting in $70 \%$ grasses $+30 \%$ legumes (30\% Dactylis glomerata $+40 \%$ Lolium perenne + $20 \%$ Medicago sativa $+10 \%$ Lotus corniculatus) was influenced by the doses of chemical fertilizers with nitrogen, thus the participation percentage ranged between $40 \%\left(\mathrm{~N}_{40} \mathrm{P}_{40}\right)-47 \%\left(\mathrm{~N}_{80+40} \mathrm{P}_{40}\right)$ at grasses, between $47 \%\left(\mathrm{~N}_{80} \mathrm{P}_{40}\right)-51 \%\left(\mathrm{~N}_{40} \mathrm{P}_{40}\right)$ at legumes, and the weeds presented between $6-9 \%$.

In the case of the mixture formed of $70 \%$ grasses $+30 \%$ legumes $(30 \%$ Festuca arundinacea $+20 \%$ Dactylis glomerata $+20 \%$ Festuca pratensis $+20 \%$ Medicago sativa $+10 \%$ Trifolium pratense) at the first cycle of harvest it was obtained a floristic composition consisting in 59-70\% grasses, $28-39 \%$ legumes and $0-6 \%$ species from other botanical families. After harvesting the first scythe, the growth of grasses decreased so much that at the II scythe the grasses participated only in a proportion between $24-40 \%$.
Analyzing the data obtained at the III scythe it is observed that the participation percentage of grasses increases proportionally with the increase of nitrogen doses from 26\% $\left(\mathrm{N}_{0} \mathrm{P}_{0}\right)$ to $39 \%\left(\mathrm{~N}_{80+40} \mathrm{P}_{40}\right)$, and the legumes decrease with the increasing of nitrogen doses from $65 \%$ $\left(\mathrm{N}_{0} \mathrm{P}_{0}\right)$ to $58 \%\left(\mathrm{~N}_{80} \mathrm{P}_{40}\right)$. The average participation percentage of the species from various group was between $0-6 \%$.

At the mixture with $80 \%$ grasses $+20 \%$ legumes $(45 \%$ Festuca pratensis $+35 \%$ Festuca arundinacea $+20 \%$ Trifolium perene), the annual average of the floristic composition changed depending on the competitiveness of the species. Thus, the average percentage of the grasses in the herbaceous cover ranged from $36 \%\left(\mathrm{~N}_{0} \mathrm{P}_{0}\right)$ to $59 \%$ $\left(\mathrm{N}_{80+40} \mathrm{P}_{40}\right)$, of the legumes from $61 \%\left(\mathrm{~N}_{0} \mathrm{P}_{0}\right)$ to $34 \%$ $\left(\mathrm{N}_{80+40} \mathrm{P}_{40}\right)$, and of the species from the various group, between 3 - 8\% (Tab. 2).

In the case of the mixture formed by Dactylis glomerata - $20 \%+$ Medicago sativa - $80 \%$, the structure of the vegetation cover was favorable to legumes, with values of 55-63\% (Fig.1).

At the $b_{2-5}$, consisting from $30 \%$ Bromus inermis $+35 \%$ Dactylis glomerata $+35 \%$ Onobrychis viciifolia, 30\% Dactylis glomerata $+40 \%$ Lolium perenne $+20 \%$ Medicago sativa $+10 \%$ Lotus corniculatus, 30\% Festuca arundinacea $+20 \%$ Dactylis glomerata $+20 \%$ Festuca pratensis $+20 \%$ Medicago sativa $+10 \%$ Trifolium pratense and $45 \%$ Festuca pratensis $+35 \%$ Festuca arundinacea $+20 \%$ Trifolium perene, at the I scythe, the grasses dominated the structure of the vegetation cover, the values obtained ranged between $63-70 \%$. At the II and III scythe the ratio has changed in favor of legumes, the recorded values were between 48 and $68 \%$ at the II scythe and $57-63 \%$ at the III scythe.

The percentage of the species from the various group has increase with the number of scythe, so at the III scythe the degree of participation in vegetation composition was of $5-12 \%$.

\section{CONCLUSION}

The 2014 was a favorable year for the studied mixtures, the perennial grasses and legumes species have developed well, and the relatively abundant rainfall fallen in spring have created favorable conditions for all plant species used in the mixtures. 
Due to the determinations made it was observed that the percentage of grasses present in mixtures decreases from I scythe to the III scythe, but instead the proportion of legumes increases.

The observations made on the participation percentage of the plant groups to the production constituting showed that the nitrogen fertilization had a significant influence on the structure of the vegetation cover. Thus, with the increasing of the nitrogen doses the competition capacity of the grasses increased to the detriment of legumes and various speciesw, but different depending on the species and the initial share in the mixture.

It was found that the share of perennial grasses decreased, and that of the legumes increased compared with the participation percentage in the sowing norm, except the mixture with Bromus inermis 30\% + Dactylis glomerata 35\% + Onobrichis viciifolia $35 \%$.

Acknowledgments. This paper was published under the frame of European Social Fund, HUMAN RESOURCES DEVELOPMENT OPERATIONAL PRO-
GRAMME 2007-2013, project no. POSDRU/ 159/ 1.5/S/132765.

\section{REFERENCES}

1. Carlsson G, Palmborg C, Jumpponen A, Scherer-Lorenzen M, Högberg P, Huss-Danell K (2006). Nitrogen fixation in cover grasslands of varied plant species richness, Biodiversity and Animal Feed "Future Challenges for Grassland production", 22:31-38.

2. Moga I, Schitea M (2005). Modern technologies of seed production at fodder plants. Ed. Ceres: 9-149.

3. Moga I., Drăgan L, Răducanu C (2007). Research regarding forage crops management at Fundulea and experimental network. Anale I.N.C.D.A. Fundulea, LXXV: 318-341.

4. Rotar I, Rusu M, Prica F (1997). The installation of some species, simple and complex mixtures, on a meadow of Festuca rubra-Agrostis tenuis, treated with the herbicide "Gliyfosate". Not. Bot.Hort.Agrobot. Cluj, XXVI XXVII: 99-107.

5. Vîntu V, Talpan I, Ionel A, Samuil C (2010). Influence of mixture and fertilization on the behavior of some grasses and perennial legume species on temporary pastures in the Moldavian forest speppe. Romanian Journal of Grassland and Forage Crops, 1:81-91. 